\begin{tabular}{|c|c|c|}
\hline Beitr. Ent. & Kelten & ISSN 0005-805X \\
\hline $\mathbf{5 4}(2004) 1$ & S. 43-52 & 28.05 .2004 \\
\hline
\end{tabular}

\title{
A revision of the Palaearctic species of Myrmecopora SAULCY, 1864. V. New taxa and new records
}

\section{(Insecta: Coleoptera: Staphylinidae, Aleocharinae, Falagriini)}

With 18 figures and 1 map

VOLKER ASSING

\section{Summary}

A subgenus and two species are described and illustrated: Anatolagria subgen. n., Myrmecopora (s. str.) virilis sp. n. (central southern Turkey), and Myrmecopora (Anatolagria) effeminata sp. n. (central southern Turkey), the type species of Anatolagria. The distributions of $M$. virilis and $M$. effeminata are mapped. Various additional records of $M$ yrmecopora are reported.

Key words

Coleoptera - Staphylinidae - Aleocharinae - Falagrini - Myrmecopora - Palaearctic region - Turkey - taxonomy - new subgenus - new species - new records - myrmecophily

\section{Zusammenfassung}

Zwei Arten und eine Untergattung werden beschrieben: Myrmecopora (s. str.) virilis sp. n. (zentrale Südtürkei), Anatolagria subgen. n. und Mymmecopora (Anatolagria) effeminata sp. n. (zentrale Südtürkei), die Typusart von Anatolagria. Habitus und die Sexualmerkmale werden abgebildet. Die Verbreitung von $M$. effeminata wird anhand einer Karte illustriert. Für mehrere Mymecopora-Arten werden weitere Nachweise gemeldet.

\section{Introduction}

An examination of material that has become available since the publication of the fourth part of the revision of Myrmecopora SAULCY (ASSING, 2001) not only yielded additional records, but also two new species and a new subgenus from Turkey, which ate described below. 


\section{Material, measurements, and abbreviations}

The material examined is deposited in the following institutions and private collections:

MHNG Muséum d'Histoire Naturelle, Genève (G. Cuccodoro)

NHMW Naturhistorisches Museum Wien (H. Schillhammer)

cAng private collection F. Angelini, Francavilla Fontana

cAss author's private collection

cEss private collection J. Esser, Berlin

cFel private collection B. Feldmann, Münster

cGol private collection V. Gollkowski, Oelsnitz

cSch private collection M. Schülke, Berlin

cWun private collection P. Wunderle, Mönchengladbach

The measurements are given in $\mathrm{mm}$ and abbreviated as follows:

TL: total length from anterior margin of labrum to apex of abdomen; AL: length of antennae; HL: head length from anterior margin of clypeus to neck; HW: maximal head width; PL: length of pronotum; PW: maximal width of pronotum; EL: length of elytra along suture from apex of scutellum to posterior margin; HTiL: length of metatibia; HTaL: length of metatarsus; HT1L: length of first metatarsomere; HT4L: combined length of second to fourth metatarsomere.

\section{Description of new taxa and additional records of Myrmecopora SAULCY}

The records listed below are commented on only when the known distributions are extended or when new bionomic data has become available.

\section{Myrmecopora (s. str.) pygmaea (SACHSE)}

Material examined: Greece: $10^{\circ}$, Voiotia, Oros Elikonas, $38^{\circ} 19^{\prime} 00 \mathrm{~N}, 22^{\circ} 50^{\prime} 13 \mathrm{E}, 1120 \mathrm{~m}$, 4.IV.2001, leg. Assing (cAss); 1 \%, Itháki, Panaghia Pernarakia, 19.IV.1972, leg. Mahnert (MHNG); 2 \% \& Pelopónnisos, Kiparissía, 5.-10.V.1956, leg. Schubert (NHMW).

\section{Myrmecopora (s. str.) wunderlei AssiNG}

Material examined: Turkey: $10,2 ㅇ ㅜ$, Antalya, Akseki, 14.III.2000, leg. Esser (cEss, cAss); $3 \sigma^{\star}$, Antalya, Alanya, Sugözü, 15.III.2000, leg. Esser (cEss, cAss).

This myrmecophilous species is apparently not rare in southwestern Anatolia. For a map illustrating the distribution see ASSING (2001).

\section{Myrmecopora (s. str.) ciliciana AssING}

Material examined: Turkey: $6 \sigma^{\star} \sigma^{\star}, 5 q+9$ [1 $\sigma^{\star}$ with worker of Crematogaster sp. attached to the pin], Mersin, Çamliyayla, 10.V.-3.VI.1963, leg. Schubert (NHMW, cAss); $2 \sigma^{\star} \sigma^{\star}$, Niðde, Giftehan, V.1966, leg. Schubert (NHMW, cAss). 
This recently described species was previously known only from one locality to the northwest of Tarsus, Mersin (Assing, 2001). The ant attached to one of the pins suggests that at least one specimen was collected with Crematogaster sp. Usually, species of Myrmecopora s. str. are associated with ants of the genus Messor FOREL.

\section{Myrmecopora (s. str.) publicana SAULCY}

Material examined: $10^{\star}, 1 \%$, Turkey, Antakya, Yayladagi, 18.III.1998, leg. Smrz (cAss, cGol); 5 o o $0^{*}, 3$ ๆ 9 , Jordan, 10 km NNE Jerash, 19.-20.IV.2002, leg. Snižek (cSch, cAss).

The distribution of this species is confined to the Middle East. In Turkey it has become known only from Antakya (Assing, 1997).

Myrmecopora (s. str.) virilis sp. n. (Figs. 1-7, Map 1)

\section{Type material:}

Holotype o: Osmaniye Asm., 1200m, 6.67, leg. F. Schubert / Holotypus ơ Myrmecopora virilis sp. n. det. V. Assing 2002 (NHMW). Paratype + [slightly teneral]: same data as holotype (cAss).

\section{Description:}

Measurements (in $\mathrm{mm}$ ) and ratios (holotype, paratype): AL: 1.59, 1.40; HL: 0.48, 0.48; HW: 0.57, 0.57; PL: 0.56, 0.54; PW: 0.63, 0.63; EL: 0.51, 0.51; HTiL: 0.87, 0.83; HTaL: 0.77, 0.73; HT1L: 0.32, 0.30; HT4L: 0.32, 0.29; TL: 3.7, 3.5; HW/HL: 1.19, 1.19; PW/HW: 1.11, 1.11; PW/PL: 1.14 - 1.17; EL/PL: 0.92, 0.94; HTaL/HTiL: 0.89, 0.87; HT1L/HT4L: 1.00, 1.05.

In facies highly similar to $M$. pygmaea (SACHSE) (Fig. 1). Colour of body dark brown, with the elytra, the posterior margins of the abdominal terga, and sometimes also the anterior parts of the anterior abdominal terga light brown to reddish brown; legs testaceous; antennae ferrugineous.

Head distinctly transverse (see ratio HW/HL), with very fine and relatively sparse puncturation; in o dorsally with very weak, almost obsolete posterior impression, in $q$ without such impression; eyes large, in dorsal view only slightly shorter than temples. Antennae very long (longer than in M. pygmaea) and with sexual dimorphism: in o longer (see measurements), preapical antennomeres distinctly oblong (Fig. 1); in $\%$ shorter, preapical antennomeres approximately as wide as long (Fig. 3).

Pronotum distinctly transverse (see ratio PW/PL) and with weak sexual dimorphism: in $\sigma^{*}$ with extensive (more than half the width of pronotum) and deep median impression extending almost over whole length of pronotum and with dense, fine, indistinctly granulose puncturation (Fig. 2); in + , too, with broad, though slightly shallower and less extensive median impression and with extremely fine puncturation (Fig. 3).

Elytra at suture slightly shorter than pronotum (see ratio EL/PL); puncturation as in M. pygmaea.

Legs very long and slender; metatarsi almost as long as metatibiae (see ratio HTaL/ HTiL); first metatarsomere approximately as long as the combined length of the three following tarsomeres (see ratio HT1L/HT4L). 


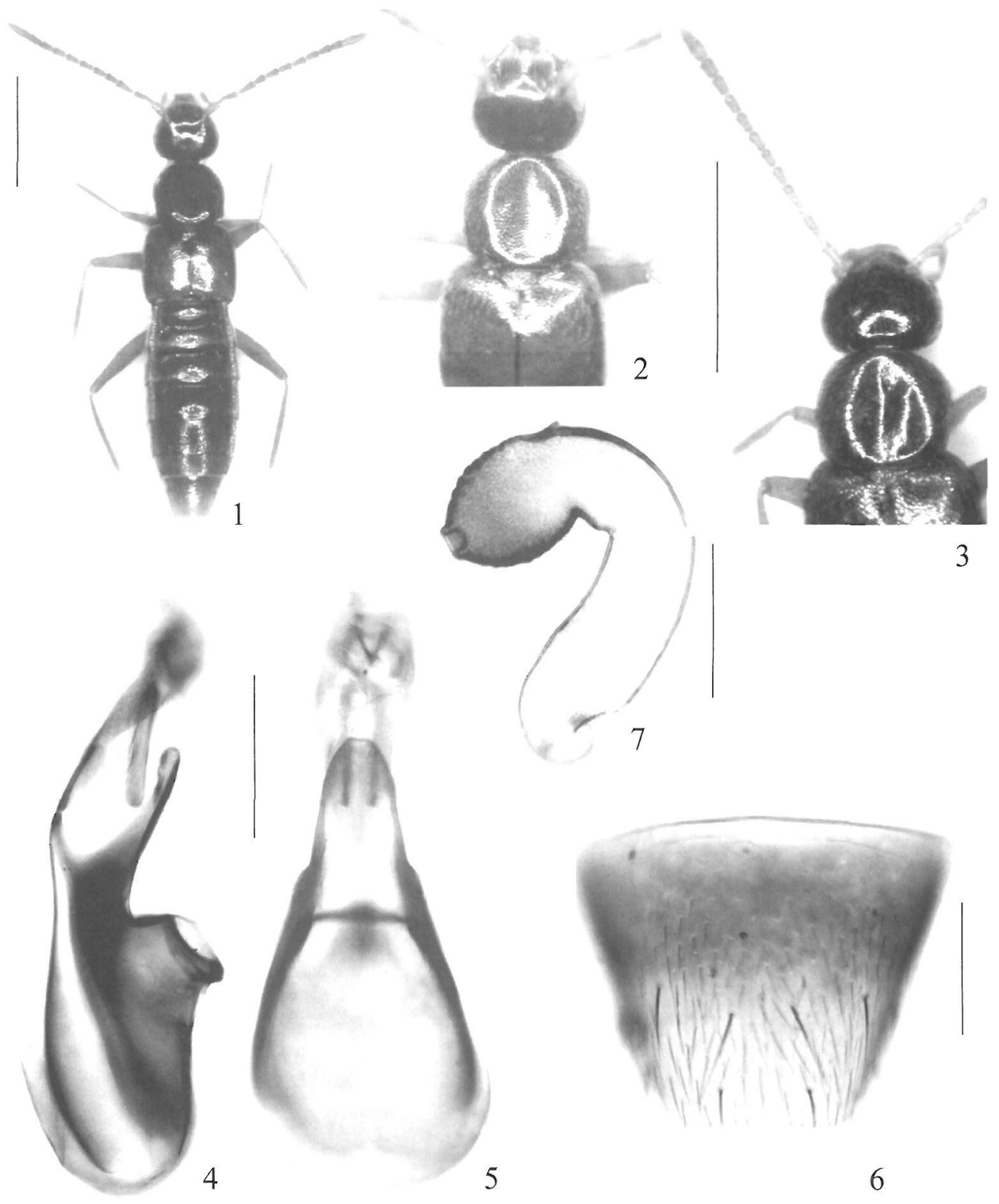

Figs. 1-7: Myrmecopora virilis sp. n.: habitus (1); male forebody (2); female forebody (3); median lobe of aedeagus in lateral and in ventral view $(4,5)$; female sternite VIII (6); spermatheca (7). Scale bars: 1 - 3: $1.0 \mathrm{~mm} ; 4$ - 6: $0.2 \mathrm{~mm} ; 7: 0.1 \mathrm{~mm}$. 


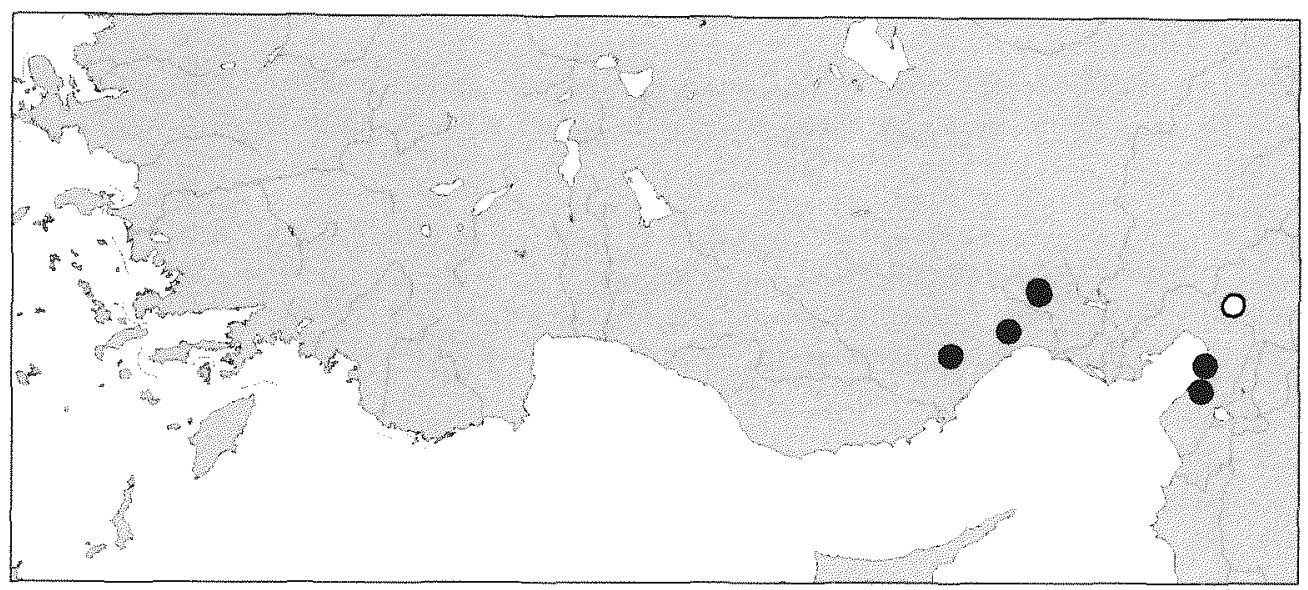

Map 1: Distributions of Myrmecopora virilis sp. n. (open circle) and M. effeminata sp. n. (filled circles) in southern Anatolia (Turkey).

Abdomen of similar morphology as in $M$. pygmaea.

$\delta^{*}$ : sternite VIII distinctly longer than the corresponding tergite, posteriorly weakly convex. and with long marginal setae; median lobe of aedeagus as in Figs. 4-5.

$q$ : posterior margin of sternite VIII truncate, in the middle indistinctly concave and with long thin marginal setae (Fig. 6); spermatheca as in Fig. 7.

Etymology: The name (Lat., adj.: manly, masculine) refers to the morphology of the female pronotum, which is of similar morphology as the male pronota of several other species of the subgenus.

\section{Comparative notes:}

From the externally similar $M$. pygmaea from the Balkans, $M$. virilis is distinguished especially by the longer legs and antennae (only little overlap), the more extensive and deeper impressions on the pronotum (in both sexes), by the relatively shorter and less slender ventral process of the median lobe (ventral view), and by the somewhat smaller capsule and the proximally wider duct of the spermatheca. Myrmecopora wunderlei AssING from southern Anatolia has a less transverse head with less marked posterior angles, a smaller and more slender pronotum with less pronounced impressions (both sexes), and genitalia of different shape. The geographically closest congeners are $M$. ciliciana ASsING and $M$. publicana SAULCY. The former is distinguished from $M$. virilis by smaller size (no overlap), shorter legs and antennae, a distinct dorsal impression on the male head, a less extensive impression and more distinctly granulose puncturation of the male pronotum, a much weaker impression on the female pronotum, and by the genitalia. Myrnecopora publicana has smaller eyes (in dorsal view distinctly shorter than temples), shorter legs and antennae, a less pronounced sexual dimorphism of the antennae, a less transverse head, a more slender pronotum with less extensive impressions (both sexes), a somewhat differently shaped median lobe of the aedeagus, and a spermatheca with a much stouter capsule and a shorter duct. 


\section{Distribution:}

The type locality is near Osmaniye, eastern Adana, in central southern Anatolia (Map 1) and situated to the east and north of the distributions of M. ciliciana and M. publicana, respectively.

\section{Anatolagria subgen. $\mathrm{n}$.}

Type species: Myrmecopora effeminata sp. n.

\section{Description:}

In general appearance somewhat resembling the falagriine genus Euphorbagria AsSING and the subgenus Iliusa MULSANT \& REY.

Head subquadrate, posterior angles evenly rounded, weakly marked; dorsally weakly convex, without impressions and without sexual dimorphism; neck slender, slightly less than one third (about $2 / 7$ ) of head width; eyes rather large; antennae relatively long and slender, apically gradually incrassated.

Labrum with membraneous appendage anteriorly; mandibles apically acute and curved, right mandible with obtuse molar tooth; maxillary and labial palpi 4- and 3-jointed, respectively, and slender (Figs. 9-11); ligula long and deeply bifid, subapically with pair of setae (Figs. 9-10).

Pronotum approximately as wide as long and as wide as head, without sexual dimorphism; midline in both sexes shallowly sulcate; hypomera visible in lateral view and separated from disk by carina; middle of prosternum obtusely pointed, posteriorly with pronounced carina. Elytra large, distinctly wider than head and pronotum. Scutellum distinctly punctate, without carina or impressions. Mesospiracular peritremes small, slender, strongly transverse, and not contiguous; mesosternal process long and acute, reaching between mesocoxae; mesocoxal acetabula margined posteriorly; mesosternum on same level as metasternum.

Legs long and slender; metatarsus slightly shorter than metatibia; metatarsomere I very long; tarsal formula 4,5,5.

Abdomen narrower than elytra, maximal width at segment $\mathrm{V}$; tergites III- $\mathrm{V}$ with transverse impression anteriorly; posterior margin of tergite VIII with long thin marginal setae, without micropubescence.

$0^{\star}$ : aedeagus of similar morphology as in Myrmecopora (Figs. 13-14); paramere with velum of condylite and paramerite distinctly separated; apical lobe of paramerite relatively long (Fig. 15). $q$ : posterior margin of sternite VIII with micropubescence; marginal setae not distinctly modified (Fig. 17); spermatheca as in Fig. 18.

\section{Systematics and comparative notes:}

The species described in the following section cannot be attributed to any of the known subgenera of Myrmecopora. The main difficulty of a (sub-)generic placement of this species arises from the fact that the characters distinguishing it from other subgenera of Myrmecopora, i. e. from the previous concept of the genus as a whole, are probably plesiomorphic and that, at the same time, it does not possess two of the constituting 
synapomorphies of Myrmecopora: the sexual dimorphism of head and pronotum, and the absence of a posterior margin of the mesocoxal acetabula. Nevertheless, in view of the similarity of many other significant characters (mouthparts, external characters, genitalia), which is here interpreted as an expression of close relationship, Anatolagria is attributed to Myrmecopora rather than regarded as a distinct genus, although the possibility that the genus is rendered polyphyletic cannot be ruled out completely.

In Eupborbagria, to which the new subgenus shows some external resemblance, the mesospiracular peritremes are large, contiguous, and subquadrate, the mesosternal process is broad, roughly rectangular, and has a rounded apex, and the mesocoxal acetabula are not margined posteriorly. In addition, the legs are less strongly elongated, the metatarsus is clearly shorter than the metatibia, and the metatarsus is much shorter, the posterior margin of tergite VIII has a comb-like row of ca. 13-15 short and very stout spines, and the paramere has a much shorter condylite and a shorter apical lobe of the paramere.

Species of Eccoptoglossa LUZE, which are of similar size, differ from Anatolagria by the trapezoid head with more pronounced posterior angles, the depressed forebody, the absence of the median sulcus on the pronotum, the posteriorly unmargined mesocoxal acetabula, the much shorter condylite of the paramere, the presence of a long flagellum in the internal sac of the aedeagus, and by a different morphology of the spermatheca.

\section{Myrmecopora (Anatolagtia) effeminata sp. n. (Figs. 8-18, Map 1)}

\section{Type material:}

Holotype o : TR - Mersin, ca. $30 \mathrm{~km}$ NNW Tarsus, $580 \mathrm{~m}$, No. 8, 37 $10^{\prime} 00 \mathrm{~N}, 34^{\circ} 45^{\circ} 40 \mathrm{E}$, fallow with decid. trees, 26.12.2000, V. Assing / Holotypus o Myrmecopora effeminata sp. n. det. V. Assing 2002 (cAss).

Paratypes: $20^{\star}, 1 \%$ : same data as holotype (cAss); $1 \sigma^{*}, 3 q q$ : same data, leg. Wunderle (cWun); $10^{\circ}$ : TR - Mersin, $30 \mathrm{~km}$ NW Erdemli, S Yagda, $1310 \mathrm{~m}, 36^{\circ} 43^{\prime} 46 \mathrm{~N}, 34^{\circ} 03^{\prime} 00 \mathrm{E}$, Abies forest, No. 16, 29.2000, Wunderle (cWun); $1 \mathrm{o}^{\circ}, 1 \mathrm{q}: \mathrm{TR}$ - Mersin, 23, $711 \mathrm{~m}$, Ciftehan - Camliyayla, pine forest, $37^{\circ} 09^{\prime} 32 \mathrm{~N}, 34^{\circ} 46^{\prime} 30 \mathrm{E}, 5 . \mathrm{V} .2002$, Meybohm (cAss); $10^{\prime}, 2$ ㅇ q : TR - Mersin, 29, Mersin - Arslanköy, $9 \mathrm{~km}$ SE Akdag, 36 54N, 3432E, 6.V.2002, Meybohm (cAss); $1 \sigma^{\star}, 1$ ' $:$ TR - Antakya, 8, 803 m, Iskenderun, Sogukoluk, 29.IV.2002, 36³9'30N, 36 $09^{\circ} 50 \mathrm{E}$, Meybohm \& Brachat (cAss); 1 \% : TR - Antakya, 14, 533 m, Iskenderun, Sogu-

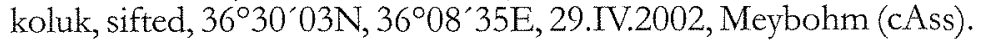

\section{Description:}

2.6 - $3.3 \mathrm{~mm}$. Habitus as in Fig. 8. Head blackish; pronotum and elytra blackish brown, usually with slight metallic hue, elytra often slightly lighter than pronotum; abdomen blackish brown to blackish, with the three anterior tergites or only their posterior margins lighter; legs light brown; antennae dark brown, with the basal two or three antennomeres lighter.

Head of subquadrate shape, approximately as wide as long; eyes large, in dorsal view slightly longer than postocular region (Fig. 8); puncturation fine and moderately dense; microsculpture absent. Antenna rather long and apically gradually incrassate; antennomere I - III distinctly oblong and of subequal length; IV and V distinctly shorter than III and weakly oblong; VI usually about as wide as long; VII - X of increasing width and increasingly transverse; $\mathrm{X}$ less than 1.5 times as wide as long; XI approximately as long as the combined length of the two preceding antennomeres (Fig. 8). 

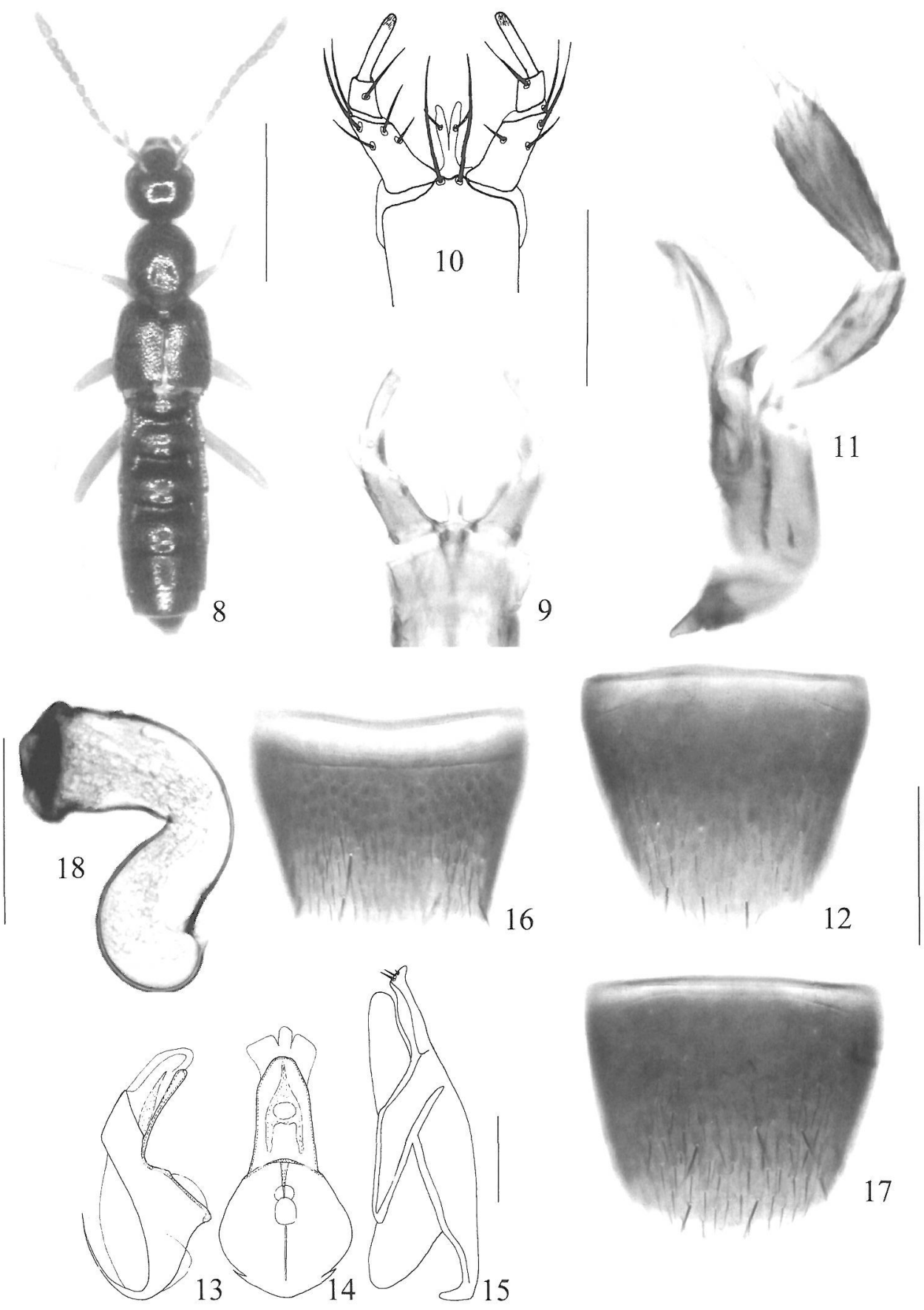

Figs. 8-18: Myrmecopora effeminata sp. n.: habitus (8); labium $(9,10)$; maxilla (11); male sternite VIII (12); median lobe of aedeagus in lateral and in ventral view $(13,14)$; paramere $(15)$; female tergite VIII (16); female sternite VIII (17); spermatheca (18). Scale bars: 8: $1.0 \mathrm{~mm}$; 12, 16 - 17: $0.2 \mathrm{~mm}$; 9 - 11, 13 - 15, 18 : $0.1 \mathrm{~mm}$. 
Pronotum about as wide as head and as wide as long (Fig. 8); puncturation rather dense, less fine than that of head; microsculpture absent. Elytra much wider than and at suture approximately as long as pronotum; puncturation rather dense, coarser than that of pronotum and weakly granulose. Hind wings fully developed. Legs long and slender; metatarsus 0.8 times as long as metatibia; metatarsomere I very long, longer than the combined length of metatarsomeres II - IV, sometimes almost as long as the combined length of II - V.

Abdomen with dense and distinct puncturation; tergites III - V anteriorly with distinct transverse impression; posterior margin of tergite VII with palisade fringe; tergite VIII in both sexes with weakly convex posterior margin (Fig. 16).

$\delta^{7}$ : sternite VIII somewhat longer than tergite VIII, its posterior margin convex and with long thin marginal setae (Fig. 12); aedeagus as in Figs. 13-15.

$q$ : sternite VIII of similar shape as in $\sigma^{*}$, posterior margin with slightly stouter marginal setae (Fig. 17); spermatheca as in Fig. 18.

Etymology: The name (Lat., adj.) refers to the absence of a sexual dimorphism of the head and pronotum.

\section{Comparative notes:}

In general appearance, $M$. effeminata somewhat resembles a small specimen of Myrmecopora fugax (ERICHSON), but is distinguished from that species by a more convex (cross-section!) and more transverse head and pronotum, the absence of a sexual dimorphism of head and pronotum, the much sparser puncturation of the forebody, and the different sexual characters.

\section{Distribution and bionomics:}

The species is known from several localities in central southern Anatolia (Map 1), where it was sifted from leaf litter in fallows and in different types of woodland.

\section{Myrmecopora (Iliusa) fugax (ERICHSON)}

Material examined: Greece: Rhodos: $10^{\star}, 1 \%$, Monolithos, 10.IV.1959, leg. Kritscher \& Paget (NHMW); 2 क \& [both with worker of Messor cf. caducus attachted to pin], Lindos, 21.IV.1959, leg. Kritscher \& Paget (cAss); 4 ㅇ q, Lindos, garden, 19.IV.1950, leg. Kritscher \& Paget (NHMW).

\section{Myrmecopora (Pataxenusa) laesa (ERICHSON)}

Material examined: Portugal: $11 \sigma^{\circ} \sigma^{\star}, 10 \% \circ$, Algarve, Praia de Faro, $37^{\circ} 01^{\prime} 00 \mathrm{~N}$, $8^{\circ} 00^{\prime} 38 \mathrm{~W}, 1 \mathrm{~m}, 26 . \mathrm{III} .2002$, leg. Lompe \& Meybohm (cAss). Spain: 19, Andalucia, Tarifa, salt meadows, 18.III.2000, leg. Aßmann (cFel).

TRONQUET (pers. comm., 2003) reports a record of this species from the Atlantic coast of France: 1 ex., l'Aiguillon-sur-mer (Vendée), 27.IX.2001, leg. Peslier. 


\title{
Myrmecopora (Xenusa) sulcata (KIESENWETTER)
}

Material examined: Portugal: $210^{\circ} 0^{\star}, 27$ o $\circ$, Algarve, Manta Rota, $37^{\circ} 08 \mathrm{~N}, 07^{\circ} 33 \mathrm{~W}$, dunes, 30.III.2001, leg. Meybohm (cAss, cFel); $60^{\prime \prime} 0^{\circ}, 1$, , Algarve, Praia de Faro, $37^{\circ} 01^{\prime} 00 \mathrm{~N}$, $8^{\circ} 00^{\prime} 38 \mathrm{~W}, 1 \mathrm{~m}, 26 . I I I .2002$, leg. Lompe \& Meybohm (cAss).

Italy: $10^{\circ}$, Calabria, Apromonte, Africo (RC), dint. foce Fiumara La Verde, 24.I.2003, leg. Angelini (cAss); $10^{*}, 1$ ㅇ, Puglia Torre Guaceto (BR), 14.IX.2002, leg. Angelini (cAng, cAss). Malta: $50^{\star} 0^{\star}, 4$ 우 웅, Ghajn Tuffieha Bay, sandy beach, 1.IV.2002, leg. Schuh (cAss).

Greece: 12 exs., Chalkidike, Olympias, leg. Franz (NHMW, cAss).

\section{Myrmecopora (Xenusa) minima BERNHAUER}

Material examined: Greece: $10^{*}$ [brachypterous], Chalkidike, Olympias, leg. Franz (NHMW).

\section{Eccoptoglossa reticuliceps AssiNG}

The sex of the holotype, which is erroneously given as " $\sigma$ " in the original description (Assing, 1999: 502), is female.

\section{Acknowledgements}

I am grateful to all the colleagues indicated in the material section for the loan of the material which this study is based on.

\section{References}

Assing, V. 1997: A revision of the Western Palaearctic species of Myrmecopora SAULCY, 1864, sensu lato and Eccoptoglossa Luze, 1904 (Coleoptera, Staphylinidae, Aleocharinae, Falagriini). - Beiträge zur Entomologie, Berlin 47: 69-151.

Assing, V. 1999: A tevision of the Palaearctic species of Myrmecopora SAULCY, 1864 and Eccoptoglassa LuZE, 1904 (Coleoptera: Staphylinidae, Aleocharinae, Falagriini). Supplement I. - Entomologische Zeitschrift 109: 499-504.

Assing, V. 2001: A revision of the Palaearctic species of Myrmecopora SAULCY, 1864. IV. A new species from Turkey and additional records (Coleoptera: Staphylinidae, Aleocharinae, Falagriini). - Beiträge zur Entomologie, Keltern 51: 335-340.

\author{
Author's address: \\ Dt. VOLKER ASSING \\ Gabelsbergerstrasse 2 \\ D-30163 Hannover, Germany \\ e-mail: vassing.hann@t-online.de
}

